\title{
Александр ЗАЙЦЕВ
}

\section{ИСТОРИЯ УКРАИНЫ ГЛАЗАМИ РОССИЙСКИХ ИСТОРИКОВ}

Новая “Истории Украины”, изданная в Санкт-Петербурге, сразу же привлекла внимание украинских историков, став поводом для критического обсуждения на сайте historians.in.ua. Оставляя оценку первых двух частей книги (до 1917 г.) более компетентным в этих периодах коллегам, я попытаюсь рассмотреть последние две части, охватывающие период с 1917 по 2011 г.

“Национальный поток Великой Российской революции”

Автором 3-й части - “Украина в ХХ веке (до 1945 г.)” - стал Александр Шубин, известный не только как чрезвычайно плодовитый историк, но и как активный деятель левого движения в России. В первых двух главах, посвященных революционной эпохе, он не стал писать нового текста, а перенес в “Историю Украины” фрагменты своей монографии "Махно и его время" (а возможно, наоборот - включил в книгу о Махно главы, написанные для “Истории Украины”). ${ }^{1}$ В отличие от других историков, для которых центральные сюжеты рассматриваемой эпохи - это война большевиков и белогвардейцев за контроль над Украиной или же борьба за ее независимость, А. Шубина больше всего привлекает борьба

1 А. В. Шубин. Махно и его время: О Великой революции и Гражданской войне 1917-1922 гг. в России и на Украине. Москва, 2013. 
народных низов за социальную справедливость и народовластие в форме Советов, в которой главными героями выступают Нестор Махно и его соратники, а также другие леворадикальные повстанцы.

Уже с первых строк автор вступает в косвенную полемику с украинской историографией, в которой события 1917-1921 гг. характеризуются как Украинская революция. Для А. Шубина мощное украинское движение было лишь одним из национальных потоков Великой Российской революции. Правда, в эту схему никак не вписывается Галиция, никогда не входившая в состав России, поэтому западноукраинские сюжеты включены в повествование лишь постольку, поскольку это необходимо для понимания событий в “большой” Украине.

Расхождения с украинским гранд-нарративом усиливаются, когда повествование доходит до вооруженного конфликта между большевиками и Центральной радой Украинской Народной Республики (УНР). А. Шубин пишет: "В наши дни войну украинских националистов и красных в 1918 году на Украине иногда называют 'агрессией России'. Но в колоннах красных шли как раз жители Украины. И они поднимали восстания за власть Советов”. И далее: “Вооруженные столкновения в декабре 1917 г. не были собственно российско-украинскими. Продолжалась борьба сторонников УНР и украинских сторонников советской власти, которым помогали российские большевики" (С. 276-277).

Действительно, среди тех, кто воевал против Центральной рады, было немало жителей Украины, в том числе и этнических украинцев. Дает ли это основания считать войну 1917-1918 гг. внутренней (гражданской) украинской войной, в которой российские большевики лишь “помогали" одной из сторон?

Обратимся к наиболее компетентным свидетелям - политическим и военным руководителям советской УНР. В то время Владимир Затонский, один из лидеров большевиков Украины, в одном из выступлений признавал: “Пока еще среди украинцев раскола нет и не предвидится, а потому приходится вести войну с украинским народом, а большевиков только небольшая горстка". ${ }^{2}$ А вот как описывает результаты решающего боя под Крутами командующий красными Михаил Муравьев: “Петроградская Красная гвардия, выборгская и московская гвардия вынесли почти одни весь бой на своих плечах". ${ }^{3}$

2 Цит. по: Т. Гунчак. Україна: перша половина XX століття. Нариси політичної історії. Київ, 1993. С. 117.

${ }^{3}$ Директивы командования фронтов Красной Армии (1917-1922 гг.): Сборник документов / Ред. Н. Н. Азовцев [и др.]. Т. 1: Ноябрь 1917 г. - март 1919 г. Москва, 1971. С. 42. 378 
Профессиональный исторический подход несовместим с чрезмерными упрощениями. Действительно, события зимы 1917-1918 гг. нельзя свести только к агрессии России - но, тем более, нет оснований сводить их только к “борьбе сторонников УНР и украинских сторонников советской власти”. Бесспорно, в них были и элементы украинской гражданской войны. Однако ядро красных войск составляли солдаты, матросы и красногвардейцы, прибывшие из России, а командовали ими российские большевики и левые эсеры, которые получали указания от петроградского Совнаркома и перед ним же отчитывались о своих действиях.

Гибридная война не изобретена в XXI веке. В 1917-1919 гг. Советская Россия вела против УНР и Украинской Державы гетмана Скоропадского классическую гибридную войну, комбинируя действия собственных войск и местных повстанцев с информационной (пропагандистской) войной, причем российское большевистское правительство публично отрицало свою руководящую роль в конфликте.

В описании войны А. Шубин определенно идентифицирует себя с одной из воюющих сторон - и его симпатии не на стороне УНР. Например, автор так описывает бой под Крутами: “Пытаясь задержать продвижение красных, петлюровцы 'во время боя насильно пустили поезд с безоружными солдатами с фронта навстречу наступавшим революционным войскам и открыли по несчастным артиллерийский огонь"” (С. 285).

Обращают на себя внимание два обстоятельства. Во-первых, анахронизм “петлюровцы" - Симон Петлюра тогда командовал только Гайдамацким кошем Слободской Украины, не принимавшим участия в бою, поэтому никакими “петлюровцами” защитники Крут ни были. Вовторых, текст содержит некую цитату, очевидно, призванную придать ему достоверность, хотя автора цитаты А. Шубин не называет. Автора легко установить: это уже упомянутый М. Муравьев, несколькими днями позже развязавший в Киеве кровавый террор, жертвами которого стали тысячи людей. Именно его донесение без комментариев цитирует А. Шубин как достоверное изложение событий, хотя жуткая история о расстрелянном поезде не подтверждена никакими другими источниками и кажется бессмыслицей с прагматичной военной точки зрения. ${ }^{4}$

Несмотря на антипатию к “петлюровцам”, А. Шубин серьезно относится к украинскому национальному проекту, однако дает понять,

${ }^{4}$ Там же. 
что он мог быть более успешным, если бы ограничился “настоящими” украинскими землями, расположенными в основном к западу от Днепра. Претензии Центральной рады и Директории на “обширные районы вплоть до Донбасса и Курска”, где, по словам автора, украинскую власть никогда не признавали, сыграли с национальным проектом “злую шутку”. Там преобладали сторонники советской власти, которым украинская национальная идея была глубоко чужда. “Для большинства жителей восточной Украины, а то и Киева или Одессы, где большинство говорило по-русски, украинское государство не было своим. Для них война против украинских националистов была войной против попытки разделить живую ткань народов, против затяжки с социальными преобразованиями”. Почему же большевики согласились на включение этих регионов в состав Советской Украины? А. Шубин объясняет: “Стремясь иметь 'свою’ Украину, большевики должны были также признать принадлежность к Украине и 'своих” восточных районов со смешанным населением” (С. 276, 280, 286, 330).

Не входя в полемику по этому вопросу, отмечу лишь, что на фоне многочисленных опусов об “исторических корнях Новороссии” или об “исконно украинском характере” Крыма и Донбасса в современной историографии не хватает действительно академических исследований истории идентичности населения востока и юга Украины, что порой ведет к неадекватной оценке современных проблем в этих регионах.

В чем А. Шубин прав, так это в критике одномерных трактовок событий 1917-1921 гг. в Украине и в их характеристике как сложного переплетения и противоборства национальных и социальных процессов и проектов. Заслуживает внимания и его объяснение причин победы большевизма, предложившего “наиболее последовательную и простую стратегию диктатуры бедноты (чем в условиях России становилась 'диктатура пролетариата'), которая нашла наиболее массовую поддержку у городских низов” (С. 329). Следствием этого стало снижение культурного уровня партии и привыкание к насилию как к универсальному средству решения всех проблем.

\section{Межвоенная эпоха и сталинская модернизация}

Если в первых двух главах А. Шубин в какой-то степени пытается представить историю “снизу”, с точки зрения народных повстанцев, а порой и обычных людей, то в последующих главах он сосредотачивается на анализе борьбы и принятия решений “наверху” и их последствий для общества. 
Автор справедливо описывает НЭП и украинизацию как результат учета большевиками предыдущих ошибок и вынужденное движение навстречу экономическим требованиям народных восстаний и национальным требованиям украинцев. Сворачивание украинизации за пределами УССР и изменение ее характера в республике он объясняет в категориях теории модернизации: переход к новому этапу индустриальной модернизации требовал культурной стандартизации в масштабах всего государства. Представляется, однако, что были и другие причины: со второй половины 1920-х гг. украинское национальное строительство начало выходить за узкие рамки, определенные для него большевистским режимом, и даже в самой Коммунистической партии (большевиков) Украины промосковской верхушке пришлось бороться с сильными “национальными уклонами”. К этому следует добавить сопротивление коллективизации, особенно мощное в Украине, и нарастание угрозы (скорее мнимой) внешнего вторжения в СССР. В результате с "империей позитивного действия" ("affirmative action empire" Терри Мартина) было покончено. ${ }^{5}$ СССР превратился в “нормальную” империю с господствующей нацией во главе.

К сожалению, А. Шубин проигнорировал базовые работы о национальной политике большевистской партии, в частности Джеймса Мейса и Терри Мартина, которых нет в списке литературы к 3-й части. ${ }^{6}$ Впрочем, как ни странно, западная историография истории Украины как будто не существует не только для А. Шубина, но и для других авторов рецензируемой книги - списки литературы к ее частям содержат названия только на русском и украинском языках.

Автор нескольких основательных исследований о сталинской эпохе, А. Шубин со знанием дела раскрывает механизмы сталинского террора, начиная с Шахтинского дела 1928 г. При этом он косвенно полемизирует с теми российскими историками и журналистами, которые расценивают Сталина как трезвомыслящего прагматика и “эффективного менеджера”: “...Стоит ли радоваться победе прагматика, если его трезвый ум служит тоталитарной машине? Тупик и крах этой машины мог оказаться для общества полезнее, чем торжество государственности, достигнутое через голод и террор".

${ }^{5}$ Cм.: Terry Martin. The Affirmative Action Empire: Nations and Nationalism in the Soviet Union, 1923-1939. Ithaca, NY, 2001; рус. пер.: Т. Мартин. Империя "положительной деятельности": Нации и национализм в СССР, 1923-1939. Москва, 2011. ${ }^{6}$ James E. Mace. Communism and the Dilemmas of National Liberation: National Communism in Soviet Ukraine, 1918-1933. Cambridge, MA, 1983. 
Вполне ожидаемо А. Шубин уделяет большое внимание причинам и последствиям голода 1932-1933 гг., который остается предметом острой дискуссии между украинскими и российскими историками. В этом вопросе автор полностью полагается на выводы историка и политика Виктора Кондрашина, которого, кстати, и российские, и украинские историки обоснованно критиковали за тенденциозность и “явно неакадемическую мотивацию". 7 А. Шубин трактует голод как результат "тяжелого выбора" сталинской группы ради завершения индустриального рывка (С. 361). Он отрицает сознательное намерение коммунистического руководства наказать крестьян голодом, а еще решительнее - концепцию специальной направленности голода против украинского народа. Вопреки большинству исследователей он пытается доказать, что “объективная оценка жертв... находится в коридоре 1-2 миллионов, а не 3-5 миллионов, как считают даже серьезные украинские историки" (С. 368). Однако и без того ужасающая цифра в 1-2 млн. явно занижена. Гораздо убедительнее подкрепленные тщательным анализом демографической статистики подсчеты группы авторов статьи в "Украинском историческом журнале", согласно которым от голода в Украине в течение 1932-1934 гг. умерло 3,9 млн. человек. ${ }^{8}$

В конце концов, А. Шубин приходит к следующему оригинальному выводу:

Вина Сталина не в том, что он сознательно стремился уничтожить как можно больше крестьян, а в холодном равнодушии к жизни нынешних людей, если ставка - будущий экономический успех. Сталин в этом отношении был подобен капиталистическим менеджерам в США и Западной Европе, которые в это же время безжалостно увольняли миллионы людей, обрекая их на голод (С. 371).

Здесь антикапиталистические политические взгляды автора явно берут верх над профессионализмом историка, побуждая его ставить на одну доску несравнимые вещи. Думаю, тот “голод”, на который “акулы капитализма" обрекали безработных во время Великой депрессии, был бы манной небесной для украинских крестьян в 1933 г.

${ }^{7}$ Г. Касьянов, А. Миллер. Россия-Украина: как пишется история. Диалоги лекции - статьи. Москва, 2011. С. 271-272; Г. Касьянов. Danse macabre: голод 1932-1933 років у політиці, масовій свідомості та історіографії (1980-ті - початок 2000-х). Київ, 2010. С. 149-150.

${ }^{8}$ Н. М. Левчук, Т. Г. Боряк, О. Воловина, О. П. Рудницький, О. Б. Ковбасюк. Втрати міського й сільського населення України внаслідок Голодомору в 1932-1934рр.: нові оцінки // Український історичний журнал. 2015. № 4. С. 84-112. 
Впрочем, там, где А. Шубин не считает нужным опровергать “тенденциозные украинские преувеличения”, его анализ сталинского террора и связи последнего с социальными и экономическими процессами довольно глубок и вполне академичен.

Переходя к истории Западной Украины между мировыми войнами, А. Шубин ступил на менее знакомое ему поприще, однако в целом неплохо справился со своей задачей, хотя и не без некоторых неточностей. Одна из них - заниженная численность украинцев в Польше $(4,3$ млн.). Заметим, что сегодня серьезные польские исследователи редко оперируют оценками ниже 5 млн. ${ }^{9}$ Однако в целом автор дает читателю довольно адекватную характеристику положения украинцев в Польше и деятельности украинских организаций, в частности Организации украинских националистов (ОУН), которой уделено наибольшее внимание.

Несколько хуже получилось с Карпатской Украиной. К примеру, деятель ОУН Рико Ярый никогда не был командующим “Карпатской сечи”, которым его “назначил” А. Шубин, поэтому теряют смысл рассуждения о том, вольно или невольно Ярый “плохо сопротивлялся венграм”, захватившим Закарпатье в 1939 г. (С. 387).

\section{Война и националисть}

В 5-й главе - “Великая Отечественная война" - А. Шубин использовал свой текст из “Очерков истории России", ${ }^{10}$ но значительно расширил украинские сюжеты, в частности, посвященные деятельности украинских националистов. Здесь автор тоже допустил ряд неточностей. Львовский, тернопольский и золочевский еврейские погромы произошли не до, а после оккупации немцами соответствующих городов. Хотя автор утверждает, что погромы совершались “силами украинских националистов” (С. 404), на самом деле причастность к ним ОУН до сих пор остается дискуссионной. Не было никаких “походных колонн ОУН численностью около 10 тыс. бойцов”, наступавших “параллельно с германскими войсками" (С. 406). Были походные группы значительно меньшей численности, имевшие не боевые, а организационные задачи. 18 тыс. солдат дивизии “Галичина" не были выданы СССР и т. д.

Впрочем, несмотря на все эти неточности, картина войны в Украине получилась достаточно полной и более-менее сбалансированной. Автор

${ }^{9}$ Cм. например: Grzegorz Motyka. Od rzezi wołyńskiej do akcji "Wisła": Konflikt polsko-ukraiński 1943-1947. Kraków, 2011. S. 17.

${ }^{10}$ Нариси історії Росії / Пер. з рос.; за заг. ред. О. О. Чубар'яна. Київ, 2007. С. 676-693. 
подробно описывает фронтовые операции, действия советских партизан, политику оккупационных властей и довольно большое внимание уделяет деятельности националистического подполья и Украинской повстанческой армии. В отличие от некоторых других историков, которые сводят деятельность ОУН и УПА к коллаборационизму и массовым убийствам гражданского населения, А. Шубин показывает, что националистическое движение преследовало собственную цель воспользоваться войной для достижения независимости Украины - и употребляло для этого все доступные средства, меняя свою тактику по ходу войны. Описаны и объяснены союз с нацистами в начале войны, его крах, переход в подполье, борьба УПА на два фронта - против немцев и советских партизан, этническая чистка на Волыни, ревизия идеологии и политической платформы ОУН, ситуативное сотрудничество с немцами в 1944 г., борьба против вернувшейся советской власти, расхождения и споры в руководстве ОУН и УПА. Некоторые предположения автора, основанные на трудах не слишком академических исследователей, весьма спорны, но в целом авторское повествование выдержано в академическом духе. А. Шубин не очерняет и не обеляет, а с большим или меньшим успехом пытается понять и объяснить действия акторов исторического процесса.

В целом, несмотря на некоторую поверхностность, фактографические ошибки, посредственное знание украинской и западной историографии, несовершенное владение украинским языком, что привело к некоторым “ляпсусам” при переводе, попытку А. Шубина стать историком Украины нельзя считать полностью неудачной, особенно на фоне политически ангажированных писаний многих других российских “украиноведов”.

\section{“Расцвет и падение Второй украинской республики”}

4-ю, заключительную часть “Истории Украины”, охватывающую 1945-2011 гг., написал Виктор Мироненко, историк, а в прошлом политический деятель, один из последних руководителей комсомола УССР и СССР. Интересно складываются человеческие судьбы: в годы горбачевской перестройки “неформал” Александр Шубин и “номенклатурщик” Виктор Мироненко были политическими оппонентами, а теперь они вместе пишут историю. Впрочем, номенклатурное прошлое дает В. Мироненко определенное преимущество: он знает историю политической верхушки позднего СССР не только из книг и документов. 
В отличие от А. Шубина, В. Мироненко больше описывает и меньше объясняет. Он начинает с описания вооруженной борьбы ОУН и УПА в западных областях Украины, где происходила "ломка жизненного уклада" местного населения. Идеологию ОУН автор определяет как “интегральный национализм", ${ }^{11}$ что не совсем точно для этого периода. Как раз в это время в националистическом подполье происходили все более глубокие идеологические изменения в направлении демократизации и усиления социальных аспектов. К началу 1950-х гг. подпольное националистическое движение в Украине постепенно избавилось от специфических черт интегрального национализма и перешло на демократическую платформу. Однако именно тогда, в течение нескольких лет после гибели командующего УПА Романа Шухевича, украинское подполье было полностью уничтожено.

Автор отмечает укрепление государственного статуса УССР в послевоенные годы (образование министерства иностранных дел, вступление в ООН, усиление роли республиканской элиты в СССР). Он полемизирует с украинскими историками, которые “любят подтрунивать” над тем фактом, что решения Москвы дублировались в УССР без каких-либо изменений:

Если бы они лучше знали специфику принятия политических решений в СССР, они бы понимали, что происходило это еще и потому, что решения эти принимались в результате очень сложного баланса внутрипартийных отношений, внутрипартийной борьбы, далеко не всегда при решающей роли, но всегда при участии украинских представителей в ЦК КПСС, его Президиуме или Политбюро (С. 454).

Автору, работавшему в позднем СССР вблизи от центров принятия решений, можно доверять. Но означало ли это, что Украина имела в СССР равноправный с Россией статус, как убеждает нас автор? Точнее будет сказать, что коммунистическая верхушка Украины, особенно после смерти Сталина, участвовала в развитии империи как “вторая среди равных", наряду с российской коммунистической верхушкой. Но происходило это ценой отречения от любых национальных интересов, отличных от общесоюзных, и слияния национальных партийных элит в единый класс советской номенклатуры. Впрочем, как показывает автор, определенный местный патриотизм, именовавшийся на партийном

${ }^{11}$ Об интегральном национализме и особенностях его украинской версии см.: Дж. Армстронг. Украинский национализм: Факты и исследования / пер. с англ. П. В. Бехтина. Москва, 2008. С. 21-24. 
жаргоне “местничеством”, часть коммунистической верхушки все-таки сохраняла, что сыграло важную роль во время распада СССР.

В. Мироненко не согласен с принятым в украинской историографии делением истории Украины 1964-1991 гг. на периоды “застоя” и “перестройки", полагая, что оно ориентируется на внешние признаки, и в нем “исчезает” собственно история Украины. Вместо этого он рассматривает время с 1953 до 1991 г. как единый “период расцвета и падения Второй (советской) украинской республики” (С. 471), хотя и выделяет в нем отдельные этапы. Такая периодизация не лишена смысла, но объединение времени позднего тоталитаризма с эпохой его демонтажа затушевывает принципиальные различия между этими периодами.

"Расцвет", по мнению автора, заключался в относительной эмансипации общества, оживлении общественно-политической и культурной жизни, поиске новых способов ведения хозяйства, мощном экономическом рывке в годы восьмой пятилетки (1966-1970 гг.) и, наконец, в ощутимом повышении уровня жизни людей. Также это время, особенно 1970-е годы, было “золотым веком” российской и украинской партийно-государственной номенклатуры.

В. Мироненко критикует современных украинских историков, которые не замечают "расцвета", за "неадекватное восприятие реалий позднего социализма" и приводит как одиозный пример следующую цитату:

В то время были широко распространены бесхозяйственность, безответственность, вседозволенность, приписки, показуха, парадная суета, разрастались коррупция, злоупотребления властью, расхищение государственной и колхозно-кооперативной собственности. Экономический и политический кризисы дополнялись моральной деградацией общества, социальной апатией, нежеланием и неумением хорошо работать, пьянством, расхождением слова и дела (С. 480). ${ }^{12}$

Однако несколькими страницами ниже автор и сам описывает “реалии позднего социализма" почти теми же словами, что и его украинские коллеги: “...Рушились нравственные устои общества, устанавливались ‘двойные стандарты' поведения - одни для других, другие для себя. Стремительно прогрессировали алкоголизм, давно превратившийся в эпидемию, коррупция, кумовство - т. н. ‘блат' и т. п.” (С. 484). Еще

\footnotetext{
${ }^{12}$ Автор, по-видимому, цитирует издание: Політична історія України: Навчальний посібник / За ред. В. І. Танцюри. 2-ге вид. Київ, 2008. Розділ 12.4. 
ниже он пишет о “хорошо известных задолго до 'гласности' фактах злоупотребления властью, коррупции и стяжательства со стороны партийно-государственной элиты" (С. 491), о бесхозяйственности и расхождении слова и дела. В чем же тогда автор усматривает “неадекватность" украинских историков? Видимо, в том, что у них преобладают “темные” стороны эпохи “застоя”, тогда как В. Мироненко видит и “светлые": уровень жизни медленно, но рос, общество становилось все более образованным и т. д. Такому “сбалансированному” подходу не откажешь в определенной рациональности, однако за ним, к сожалению, не просматривается убедительного ответа на ключевой вопрос: почему советская система стремительно обрушилась на рубеже 1980-х и 1990-х гг.?

Автор пытается подвести читателя к пониманию причин этого явления, подробно рассматривая показатели развития и постепенной деградации советской экономики, при этом перегружая текст многочисленными цифрами, процентами, тысячами тонн, миллионами пудов и т. п., так что временами повествование начинает напоминать комментированный статистический справочник.

Нельзя сказать, что повествование игнорирует человеческий фактор. Правда, большинство выдающихся личностей того времени перечислены через запятую и лишь портреты некоторых руководителей республики получились довольно рельефными. Особенно это касается Владимира Щербицкого. В отличие от большинства украинских историков, В. Мироненко описывает деятельность Щербицкого с уважением и даже с определенным сочувствием, особенно когда рассказ доходит до обстоятельств его отставки.

Однако исключительное внимание к “людям наверху” привело к тому, что почти вся история перестройки сведена к личным отношениям между Михаилом Горбачевым, Владимиром Щербицким, Владимиром Ивашко, Леонидом Кравчуком, Борисом Ельциным и другими партийными деятелями. Даже упоминая о создании Народного руха Украины, автор больше пишет о предполагаемой роли в этом процессе секретаря ЦК КПУ Л. Кравчука, ${ }^{13}$ чем о самом Рухе. Еще меньше повезло другим “неформальным" организациям, студенческим протестным акциям и новым политическим партиям, которых автор и вовсе “не заметил” (допускаю, что бывший неформал А. Шубин написал бы этот раздел иначе).

${ }^{13}$ На самом деле Л. Кравчук в то время был заведующим идеологическим отделом ЦК КПУ, а секретарем ЦК стал в октябре 1989 г., т. е. уже после создания Руха. 
У читателя может сложиться впечатление, что даже распад СССР был результатом деятельности двух человек - Б. Ельцина и Л. Кравчука, которые своей “скоординированной работой” блокировали попытки М. Горбачева сохранить союзное государство, а довершил его разрушение т. н. “августовский путч” в 1991 г. После этого был принят Акт провозглашения независимости Украины, и Л. Кравчук “тайно от Президента СССР” договорился со своим российским и белорусским коллегами о срыве подписания нового союзного договора и, в конце концов, о ликвидации Союза. Так, по словам автора, “умерла” Вторая украинская республика (С. 494-496).

В этой схеме не хватает анализа глубинных причин распада советской империи, а весь процесс сведен к стечению (не)благоприятных обстоятельств и личным амбициям лидеров.

Для Украины наступило новое время - эпоха “третьей украинской республики”. “Тогда мало кто еще понимал, - пишет автор, - что в этом новом времени за бывшей на слуху проблемой государственного суверенитета России и Украины зримо и грозно замаячила другая проблема взаимоотношений России и Украины...” (С. 496).

\section{“Третья украинская республика”: утраченные иллюзии}

Историю независимой Украины В. Мироненко описывает преимущественно в пессимистическом тоне. Некоторым исключением стала лишь характеристика деятельности Леонида Кучмы на постах премьер-министра и президента. Здесь автор опять не соглашается с украинскими историками:

Оценки деятельности второго Президента Украины в украинской историографии очень противоречивы и скорее негативные, чем положительные. На наш взгляд, это не справедливо. В существовавших тогда условиях, в целом, ему удалось провести украинский государственный корабль через сложнейший и опаснейший для молодого государства переходный период с минимальными потерями и к концу своего президентства обеспечить его относительную политическую и экономическую устойчивость. То, что он до сих пор “на плаву” - несомненная заслуга простых украинцев и Л. Кучмы, вышедшего из их среды и хорошо их понимавшего (С. 501).

Заслугу Л. Кучмы автор видит, в частности, и в том, что тот укрепил власть президента до полуавторитарной и этим, наряду с умеренными 
экономическими реформами, обеспечил относительно мирное выживание украинского общества. Однако существует и другой взгляд на годы правления Л. Кучмы: именно тогда был окончательно потерян шанс быстрого перехода к демократии и социально-ориентированной рыночной экономике, начавшегося в конце 1980-х и продолжавшегося до середины 1990-х гг. Вместо этого в Украине утвердилась клановоолигархическая модель капитализма с политической надстройкой в виде “шантажистского государства". ${ }^{14}$

Одним из достижений этой эпохи В. Мироненко считает подписание “Большого договора" между Украиной и Россией 1997 г., который, хоть и был скорее декларативным, все же стал важной вехой в развитии межгосударственных отношений. Характеристику, которую автор дает договору, сегодня невозможно читать без сарказма:

Общепринятые нормы международных отношений: взаимное уважение, суверенное равенство сторон, территориальная целостность и нерушимость границ, мирное урегулирование споров и отказ от использования силы или угрозы силой, включая экономические и иные способы давления, невмешательство во внутренние дела, взаимное соблюдение прав и свобод человека, выполнение принятых обязательств - в историческом контексте и в контексте двусторонних российско-украинских отношений звучали очень актуально (С. 504).

Остается пожалеть, что автор не довел своего изложения хотя бы до 2014 г. - был бы повод сопоставить эти прекрасные принципы с реальностью.

Осень и зиму 2004 г. (время “оранжевой революции”) В. Мироненко определяет как конец политической и экономической устойчивости и “первую общественно-политическую бифуркацию в Украине”. Он предлагает довольно интересную оценку причин неудачи “оранжевой революции":

Фактическая неудача реформ и дискредитация идей, поднявших в те дни множество украинских граждан на борьбу за свои права, была предопределена тем, что массовой базой движения протеста были представители естественно возникшей и окрепшей без государственной помощи среды мелкотоварного производства и местного товарообмена, о котором шла речь выше. А во главе

${ }^{14}$ См., например: Г. Касьянов. Украина 1991-2007: очерки новейшей истории. Киев, 2008. Гл. 3-4; Вместо послесловия. 
движения встали люди, связанные с крупным новым капиталом, сформировавшимся на бесплатной по существу приватизации и внешней торговле. Или люди, очень быстро перешедшие в этот лагерь (С. 506-507).

Свое изложение В. Мироненко заканчивает довольно пессимистическим итогом: украинское государство так и не стало ни демократическим, ни правовым, ни, тем более, социальным.

Пока что украинская государственность в конкретно-исторической форме третьей украинской республики представляет собой большей частью лишь территорию и совокупность людей, живущих на ней, без ясно выраженных общих целей, обязательных для всех правил поведения и ведения бизнеса, без определенной внешнеполитической ориентации (С. 507).

Относится ли этот вывод только к состоянию украинского государства к 2011 году, которым завершается “История Украины”, или в той же мере и к его современному состоянию? К сожалению, хотя книга издана в 2015 г., авторы не включили в нее описания драматических событий последних лет. Подозреваю, не только потому, что историческая оценка недавнего прошлого требует временной дистанции, но и потому, что дальнейшее изложение потребовало бы от авторов четких ответов на прямо поставленные вопросы о природе политики Путина в отношении Украины. Однако российское общество еще не готово к такому разговору.

Впрочем, если не в академических текстах, то в своих интервью и А. Шубин, и В. Мироненко занимали достойную позицию, осудив и аннексию Крыма, и необъявленную войну России против Украины. ${ }^{15}$ Это позволяет надеяться, что честная история украинско-российских отношений последних лет когда-нибудь будет написана.

$$
* \quad * \quad *
$$

Взгляд на любую национальную историю “извне” имеет свои преимущества: зарубежные историки имеют больше шансов подняться над мифами и предубеждениями, присущими каждой национальной историографии. Однако эти преимущества могут быть сведены на нет, если речь идет об истории государства, в отношении которого в

${ }^{15}$ Александр Шубин: присоединение Крыма - клин между народами // Кавполит. 22.03.2014. http://bit.ly/2fGyO8s; Советник Горбачева: в Украине сейчас решается судьба всего мира // Обозреватель. 5.05.2015. http://bit.ly/2fUvap6. 
обществе, к которому принадлежит историк, сформирован образ врага. Следует отдать должное авторам “Истории Украины”: в непростых условиях украинофобии и антизападных настроений, культивируемых в нынешней России, они все же стараются придерживаться декларированных во введении академического стиля и отказа от политизации. Во всяком случае, не заметно, чтобы события последних лет побудили их отредактировать свои тексты в духе путинской идеологии. Уже только это в наше время - немалая заслуга.

Чтение книги оставляет двойственное впечатление. Если она является обобщением новейших достижений научного российского украиноведения, то напрашивается вывод, что его нынешнее состояние оставляет желать лучшего (впрочем, как и состояние изучения России в Украине). Однако на фоне политизированных, а то и откровенно пропагандистских писаний многих историков, увенчанных докторскими и кандидатскими степенями, книга четырех российских авторов выглядит чуть ли не образцом академического подхода. Как пессимистически прокомментировал ее появление один российский сайт, “на фоне опасно разбухшего потока псевдонаучных текстов о 'духовных корнях Новороссии' и т. д. ... возможно, это последний беспристрастный труд по истории Украины на ближайшие годы". ${ }^{16}$

\section{SUMMARY}

This review essay critically discusses the chapters of the collective monograph The History of Ukraine (St. Petersburg: Aleteia, 2015) penned by Alexander Shubin and Viktor Mironenko.

${ }^{16}$ История Украины // Книжный магазин в Петербурге “Все свободны”. 30.03.2015. http://bit.ly/2glQYuM. 